\title{
Sarvak Reservoir Facies Characteristics in One of the South West Field in Iran
}

\author{
Somayeh Pakparvar, Nader Kohansal Ghadimvand, Davood Jahani \\ Department of Geology, Faculty of Sciences, Islamic Azad University, Tehran North Branch, Tehran, Iran \\ Email: S_pakparvar@yahoo.com, N_kohansal_ghadimvand@iau-tnb.ac.ir, Jahani_davood@yahoo.com
}

How to cite this paper: Pakparvar, S., Ghadimvand, N.K. and Jahani, D. (2017) Sarvak Reservoir Facies Characteristics in One of the South West Field in Iran. Open Journal of Geology, 7, 279-294. https://doi.org/10.4236/ojg.2017.73020

Received: December 27, 2016

Accepted: March 19, 2017

Published: March 22, 2107

Copyright $\odot 2017$ by authors and Scientific Research Publishing Inc. This work is licensed under the Creative Commons Attribution International License (CC BY 4.0).

http://creativecommons.org/licenses/by/4.0/ c) (i) Open Access

\begin{abstract}
Sarvak Formation (Late Albian-Early Turonian) as main reservoir in the field is one of the carbonate units of Bangestan Group in Zagros Basin with average thickness of $640 \mathrm{~m}$. This formation conformably overlays the Kazhdumi Formation while the upper boundary is an erosional unconformity which is covered by Ilam Formation. There is a significant lateral and vertical heterogeneity in the reservoir layers that causes main challenge in reservoir characterization. In this paper, reservoir properties evaluation and construction of depositional model have been done based on lithotype study, sedimentary environment classification, petrophysical interpretations and SeisWorks. Five facies types (lithotypes) in the Sarvak Formation with particular rock properties are identified in 8 wells and 200 thin sections. The main facies association elements and relevant depositional settings have been interpreted by extracted Paleolog, facies and fossil association data which are related to depositional setting variations.
\end{abstract}

\section{Keywords}

Lithotype, Heterogeneity, Paleolog, Depositional System

\section{Introduction}

The carbonate platform deposits of the Sarvak Formation were deposited in Late Albian to Early Turonian age [1] [2] [3] as the second most important carbonate reservoir in the Zagros Basin. This formation is a thick carbonated unit that is deposited in Neotethys Southern Margin of Zagros Basin. In the past, this rock unit was called Hipporite limestone, Rudist limestone and Leshtegan limestone, but with sectional measurement in Sarvak rock unit at Bangestan mountain, the Sarvak Formation substituted former names. The Sarvak Formation includes mostly carbonate in lithology and was composed of sequence of thin to medium-bedded limestone and massive limestone [1]. This formation predominantly characte- 
rized by cyclic stacks of shallow-marine carbonates and has recently been investigated in detail as a reservoir rock [4] [5]. The Sarvak Formation attains about $800 \mathrm{~m}$ thin, and medium to thick carbonate layers in thickness in its type section (Bangestan Mountain in vicinity of Izeh area). It conformably overlies the Kazhdumi Formation and unconformably covers by the argillaceous Gurpi Formation [3].

There are several investigations on the Sarvak Formation sedimentary and reservoir properties [6]-[12]. The present study has been focused on the eight wells with special emphasis on the lithotypes analysis, sedimentary environments, and reservoir properties evaluation of the Sarvak Formation.

\section{Material and Methods}

According to lithotype study, sedimentary environment, petrophysical interpretations and SeisWorks of the Sarvak Formation, eight wells in one of the south west field in Iran were studied. A total of 200 thin sections of these wells were analyzed. Thin sections were stained with Alizarin Red-S and potassium ferricyanide [13] to determine mineralogical and qualitative elemental composition of the studied carbonates. Carbonate microfacies is described based on [14] with the modifications of [15] classification. Facies belts and sedimentary models of [16] and [17] were also applied. Lithotypes of this oil field reservoir formation including Sarvak Formation have been studied and classified using all available facies data and relevant petrophysical interpretations of drilled wells and Paleo logs. The available Paleologs from appraisal wells and some scattered core analysis reports have been reviewed and used as the main source for the following lithotype classification of Sarvak reservoir layers. The following parameters were used for introducing the lithotype identification:

- The main rock lithology, achieved by petrophysical interpretations and sedimentological core review.

- Facies associations, interpreted by Paleolog data and sedimentological core review.

Reservoir quality was identified by petrophysical interpretation, shale volume and porosity values. The sedimentary environment reconstruction and depositional model analysis have also been individually done in this paper for Sarvak Formations, on the basis of the lithotype distributions and sedimentary environment classifications.

The seismic data from this study field shows a significant lateral and vertical seismic heterogeneity along the different reservoir layers, caused by lateral and vertical lithofacies changes. Based on the available interpreted acoustic impedance profiles, the distinct heterogeneities occurred in the Sarvak carbonate successions, influenced by seismic channelized system and significant facies changes, caused by eustatic sea level changes. It is stressed that the AI index can be influenced by many seismic properties and rock volume contents. For instance, the shale volume has a big effect on the AI values, which causes noticeable decrease of the rock density. In such condition, the shale volume is consi- 
dered as one of the main criteria in order to classify the discussed lithotypes for each reservoir layer. One of the major observations in the interpreted seismic profiles is particular channelized feature, which is concentrated in the Upper Sarvak reservoir unit.

\section{Results and Discussion}

\subsection{Lithotype Analysis}

Lithotype classification of the Sarvak Formation in the study field has been performed on the basis of the available geological subsurface data, particularly paleolog interpretation. At least five facies types (lithotypes) were identified in the Sarvak Formation with particular rock properties, consisting of individual facies associations, shale volume, reservoir quality and petrophysical signatures. The discussed lithotypes were identified and followed in number of selected this field wells. The main facies association elements and relevant depositional settings have been interpreted by extracted Paleolog facies and fossil association data, which is related to depositional setting variations. It is attempted to define a lithotype with particular sedimentary environment and distinct reservoir quality, ranged from non to high values. There is a geological/petrophysical lithotype classification that should be completed and revised as the next step by adding reservoir data. The microfauna assemblages have also been reviewed in order to interpret the major sedimentary environment for each Sarvak reservoir zone. The Sarvak reservoir interval is characterized by the following correlatable lithotypes:

- Lithotype 1: Argillaceous muddy facies to fossiliferous (low to non-reservoir rock).

- Lithotype 2: Mud-dominated carbonate facies (bioclastic wackestone to packstone) with partly dolomitized facies (dominantly low reservoir quality).

- Lithotype 3: Rudist bearing facies (medium to coarse grained Rudist/Coral rudstone to floatstone) commonly high reservoir quality.

- Lithotype 4: Mostly cemented bioclastic grain-dominated carbonate facies (peloidal/bioclastic packstone to grainstone) moderate to low reservoir quality.

- Lithotype 5: Claystone (non-reservoir rock).

The lithotype 1 is characterized by muddy carbonate facies that has a small contribution in the Sarvak interval and is also classified as low to moderate reservoir quality. This facies was more developed in the upper and intra Sarvak intervals. The noticeable gamma ray radiation (due to clay contents) and low porosity index are the main criteria in order to distinguish this type of lithotype. In terms of depositional setting, it is more related to the restricted muddy carbonate platform (lagoonal to peritidal settings), affected by noticeable karstification and consequent dissolution processes.

The lithotype 2 is a fine grained bioclastic/peloidal wackestone to packstone (mud-dominate to grain-dominated), representing a restricted to semi restricted carbonate facies with a wide range of bioclasts and other carbonate components. 
This particular carbonate lithotype is more dominant in the basal part of the Upper Sarvak and Lower Sarvak intervals in the study Field. In terms of the depositional setting, the mentioned lithotype is deposited in the open shelf lagoon to proximal part of open marine sedimentary environment. A varied range of disconnected porosity such as vuggy and skeletal moldic with different pore size distributions can be observed in this bioclastic fine grained and heavily micritized lithotype. Anyway, this facies is classified as low to moderate reservoir quality; due to lack of any connected porosity and negligible facies distribution along the upper Sarvak interval.

The lithotype 3 is the main reservoir facies in the Sarvak Formation, particularly in the upper Sarvak interval. This lithotype is characterized by aggradation of the large to medium size of the rudist/echinoderm/coral fragments that placed among the carbonate cement or carbonate/clay matrix (varied range of gamma ray radiation, affected by different clay contents). The Rudist bearing rudstone facies (grain-supported and lack of any matrix) is characterized by high effective porosity and lowest clay contents. Whilst, the Rudist bearing floatstone (mudsupported with noticeable clay contents) has less reservoir quality and is marked by distinct gamma ray radiation. They have created a particular facies type with noticeable reservoir quality. The lithotype 3 is dominant in the upper Sarvak and Mauddud equivalent (lower Sarvak) intervals, particularly in the Sarvak zone-3 to Sarvak zone-8 as the main producer reservoir layers.

The lithotype 4 is comprised of fine to medium grained bioclastic/peloidal packstone to grainstone (influenced by pervasive carbonate cementation and micritization) facies types as a porous to semi-porous grain-dominated lithotype. It is developed in the different parts of Sarvak interval, particularly in the upper Sarvak unit as a one of the prolific reservoir rock (less than the Lithotype 3 in terms of the reservoir quality). The micritized peloids and skeletal debris are common in this lithotype and some pore space was filled by secondary calcite cementation and compaction on the basis of the core review. The rate of gamma ray radiation is very low, due to lack of any clay contents and roughly carbonate cementation, nevertheless, the rate of porosity (effective porosity) is moderate to high in some samples in comparison with the lithotype 3 , caused by partly dissolution process.

The lithotype 5 is a pure claystone with non-reservoir quality (plays as a barrier in the Upper part of Sarvak Formation) and has a sealing potential particularly in the Laffan shale unit. Based on the recent petrophysical interpretation of the involved wells, there are some intervals having more that 50 percent clay content, automatically ranked within this lithotype. The carbonate contents declined to less than 20 percent (calculated lithology percentage) in this argillaceous lithotype. The biggest interval comprised of the mentioned litho-type are respectively Sarvak zone- 2 and Ahmadi shale (a part of intra Sarvak zone). The overlying Laffan shale is also comprised of lithotype 5 and deposited in the restricted to peritidal environments (documented by lack of any marine fossil contents). The argillaceous Ahmadi interval shows more carbonate contribu- 
tions, deposited in the distal open marine setting and essentially characterized by significant pelagic microfauna and marked by high radiation of gamma ray (CGR and SGR values). The relevant Sarvak lithotypes correlation (across the discussed transect) with vertical and lateral changes among the selected wells are exhibited in the Figure 1 and Figure 2.

The Sarvak lithotypes were aggraded to prograded vertically and laterally in the study area, caused by eustatic sea level changes and local tectonic emergence. The relevant reservoir qualities are significantly controlled by facies properties (grain size, pore type and matrix type), depositional environments and diagenetic impacts (dolomitization and dissolution processes) that normally increase or decrease the reservoir quality. The major volume of reef builder fragments such as Rudist and Coral debris influxed into the Sarvak basin, due to gradual sea level falling and temporary subaerial exposure. The individual facies (Lithotype) influenced the Sarvak Formation in Abadan Plain region that can be observed predominantly in the whole Sarvak successions (particularly in the study Field). Therefore, the medium to large grained bioclastic grain-dominated carbonate facies (mainly constituted by Rudist fragments) with noticeable reservoir quality and varied ranges of petrographical porosity types are classified as the best reservoir lithotype in the Sarvak interval. There is a relationship between Rudist fragments influxes and gradual sea level falling to subaerial exposure, so that this particular Rudist bearing facies dominated in the upper part of Sarvak Formation, influenced by Late Cenomanian to Early Turonian shallowing upward cycles and several small-scale subaerial emergences (stratigraphical disconformity to paraconformity). The channelized seismic features that crossed the study field, affected by unidirectional influxes of the huge carbonate bioclastic debris into the deeper basin, accurately from North East to South West. It is originated by long term emergence of the massive reef builders (Rudist frag-ments are dominant) in adjacent of the study area during the Late Cenomanianto Early Turonian ages. Based on the subsurface observations and seismic interpretation, the Rudist bearing channelized features are more dominant in the upper Sarvak interval, limited between Sarvak zone- 8 to Sarvak zone-3 (Figure 3). The upper Sarvak Rudist bearing facies type (as the first rank of the reservoir quality) is

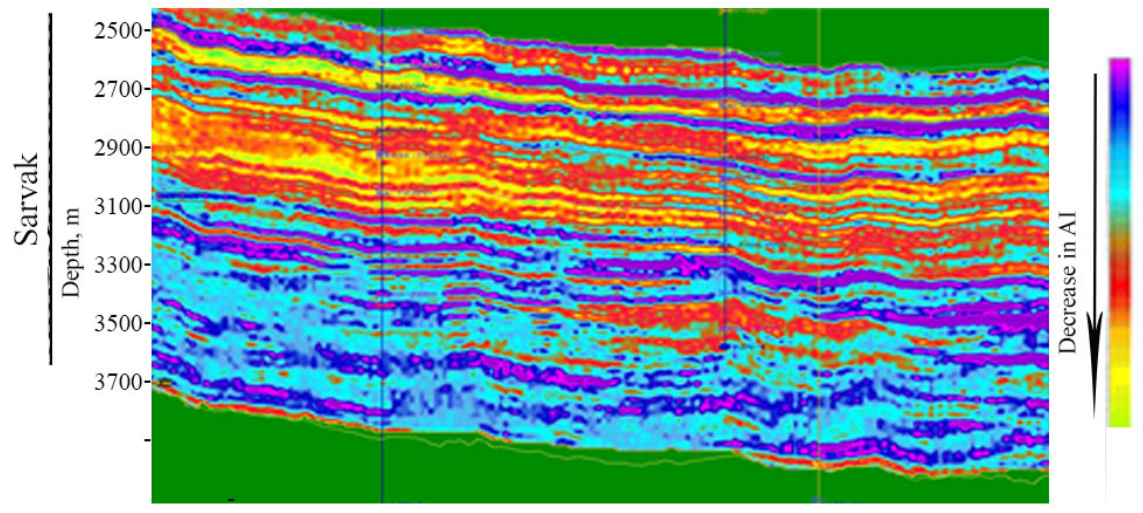

Figure 1. AI seismic profile among the number of wells in the study field. 


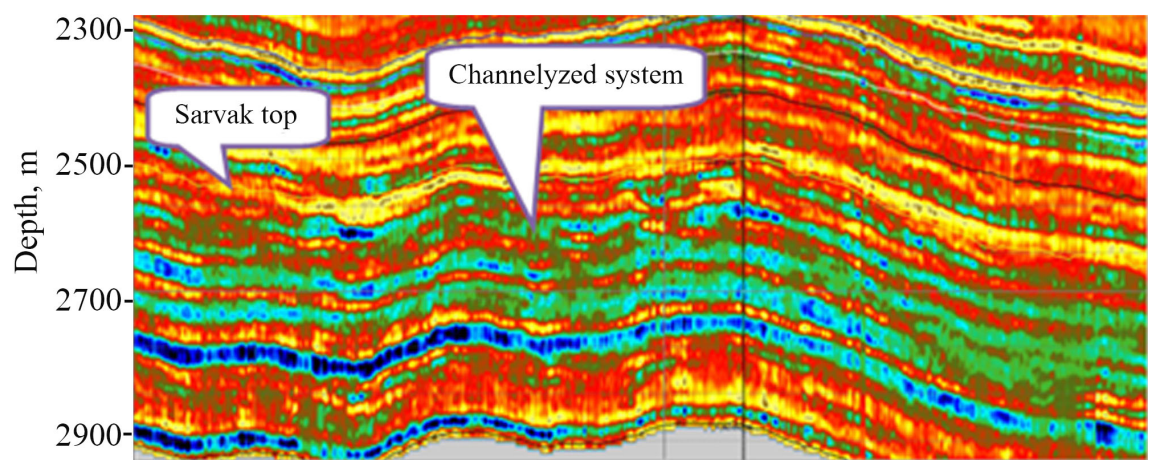

Figure 2. Channelized features in one of the study field seismic profile.

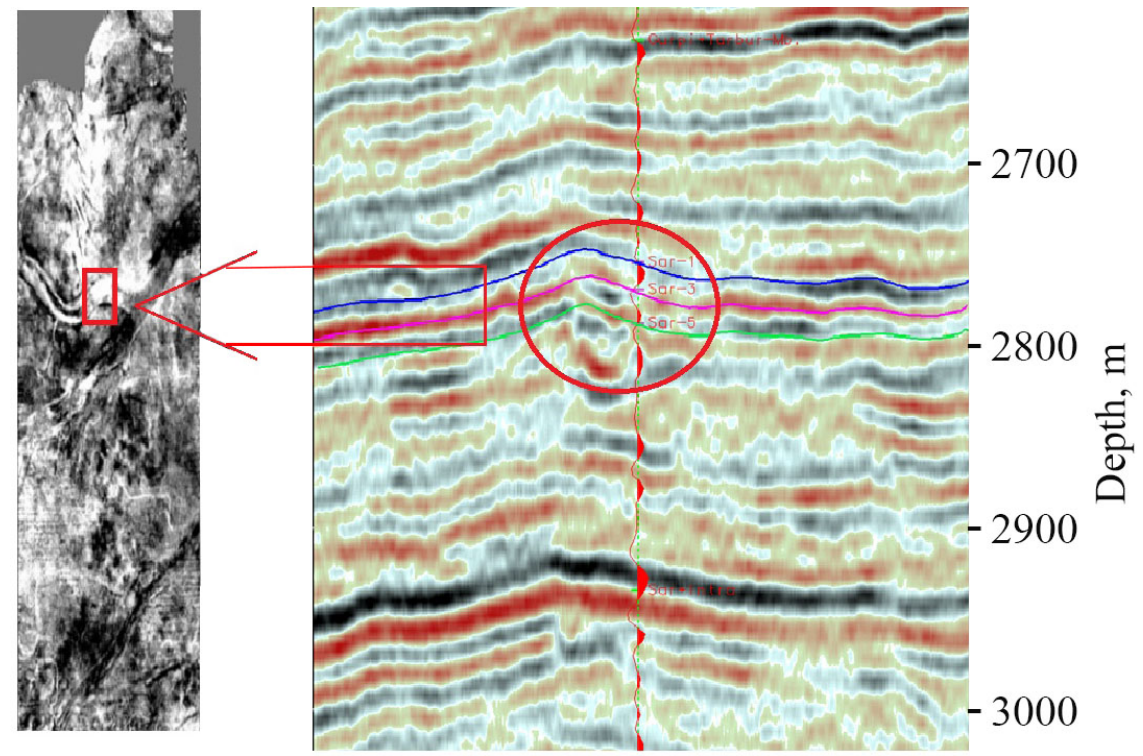

Figure 3. Sarvak channelized Rudist bearing facies type in the study field.

overlain by Early Turonian disconformity surface, which is adapted with the lower boundary of the Sarvak zone-2 (reddish claystone with brecciated features), representing a distinct subaerial exposure, generated karstification features subsequently (meteoric diagenesis) that increased the volume of the vogular porosity in the underlaying leached carbonate succession (corresponds to the Sarvak zone-3 to Sarvak zone-8). The widespread dissolution events (karstification) that caused by subaerial exposure in the humid condition, affected irregularly the underlying carbonate successions and leached the solved unstable lime muddy matrix (generated noticeable vogular porosity with different pore size distributions). It is noted that the reservoir quality is not the same characteristics in the channelized Rudist bearing facies (affected by erosion), due to different impacts of the diagenetic processes. On the other hand, the existing channels (as a submarine channel) are generated by claciturbidite events after big erosion or reef builder aggradation in the Sarvak platform margin, consequently influxed into the clinoform of the basin. There is a unidirectional channel system that rapidly crossed the clinoform and then expanded as a finger bird shape into the more flat deep sea plane. The AI seismic interpretation reveals that the main part 
of straight channels, where crossed the study Field are predominantly cemented, representing high AI (acoustic impedance) and commonly low reservoir quality. Whilst, the marginal area of the submarine straight channels (corresponds to the Levee portion) demonstrates a moderate to low AI zone, can be interpreted as moderate to high reservoir quality. It is noteworthy that the finger bird shapes that are situated in the distal part of the channels show the best reservoir quality and lowest range of carbonate AI.

The upper part of Sarvak reservoir (as the main reservoir column in the study Field and adjacent areas) was overlain by regressive argillaceous facies, called Laffan shale. It seems that the topmost part of the Upper Sarvak carbonate is placed between two overlying (Laffan Shale) and underlying (Sarvak zone-2) regressive shales, just affected by Turonian disconformity event. The Sarvak zone1 is sandwiched between two discussed shale stacks and deposited during Early Turonian age (a part of Zoe 24 or Zone 29 of [1]. The results of this phase of study represents that the Sarvak zone-1 is characterized by a mixture of carbonate lithotypes, ranged from some scattered Rudist bearing facies to tight carbonate lime mudstone. It seems that the reservoir quality is increased locally in this zone by presence of patchy Rudist bearing bodies or settlement of the semi-porous bioclastic grain-supported facies (lithotypes 3 and 4). It is noted that this mentioned reservoir zone is more dominated by Rudist bearing/grainsupportes facies with fair reservoir quality in the mid to northern part of the field, where the maximum channelized features can be seen (Figure 4 and Figure 5).

\subsection{Core Review}

In this paper, we used core data from number of wells represent a distinct relationship between the set of porosity and permeability relationship in the Upper Sarvak unit that was cored in the above mentioned wells, representing different

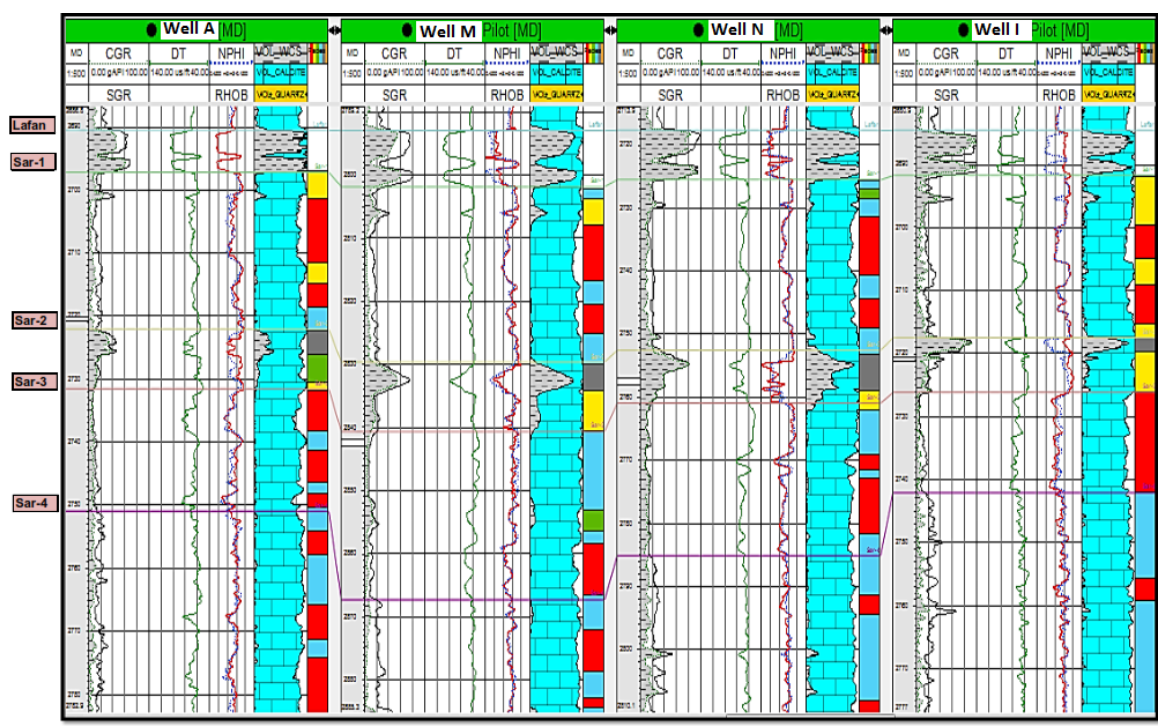

Figure 4. Sarvak lithotypes distribution in zones (Sar-1 to Sar-4). 
relation and showing a varied types of porosity distribution (Figures 6-9). The following porosity/permeability cross plots indicate that the reservoir characteristics and relevant porosity types and its distribution can vary in different reservoir zones and wells, affected significantly by sedimentary environment changes, local digenetic events, facies properties and vertical/lateral heterogeneity.

In well $\mathrm{A}$, core review represents that the cored interval is placed around Sarvak zone-3 showing the high porosity rock $(20 \%-25 \%)$ and moderate to low permeability (between 1 to $10 \mathrm{md}$ ), representing a carbonate stack with development of vugular disconnected porosity, caused by leaching digenetic process (Figure 6). The well B, core review represents that the cored intervals are placed around Sarvak zones- 3 and 4 showing an ascending relationship between porosity and permeability, representing a carbonate stack with development of connected interparticle porosity, caused by accumulation of the Rudist debris with considerable interpores, accompanied with subsequent meteoric digenetic process (Figure 7). The well C, core review demonstrates that the cored intervals are placed around Sarvak zones-3 and 6 illustrating two different data communities in terms of porosity and permeability relationship, representing two carbonate stacks with different type of reservoir characteristics and porosity type. Based on this cross plot, Sarvak zone-3 is classified as the best reservoir quality and the Sarvak zone- 6 ranked as moderate to low reservoir quality (commonly the rate of permeability is less than $1 \mathrm{md}$ ), enhanced by small size connected pores and $\mathrm{k} /$ phi ascending relationship (Figure 8 ). The well $\mathrm{D}$, core review reveals that the cored intervals are concentrated around Sarvak zones-2, 3 and 4 illustrating two different data communities in terms of porosity and permeability relationship, representing two carbonate stacks with different type of reservoir characteristics and pore type. Based on this cross plot, Sarvak zone- 3 can be considered as the best reservoir quality with dominant connected porosity and large size of vuggy pores, Sarvak zone-4 indicates more heterogeneity that mixed by a part of zone- 3 data showing disconnected vugular porosity, the zone- 2 is also placed as low to non reservoir quality (Figure 9).

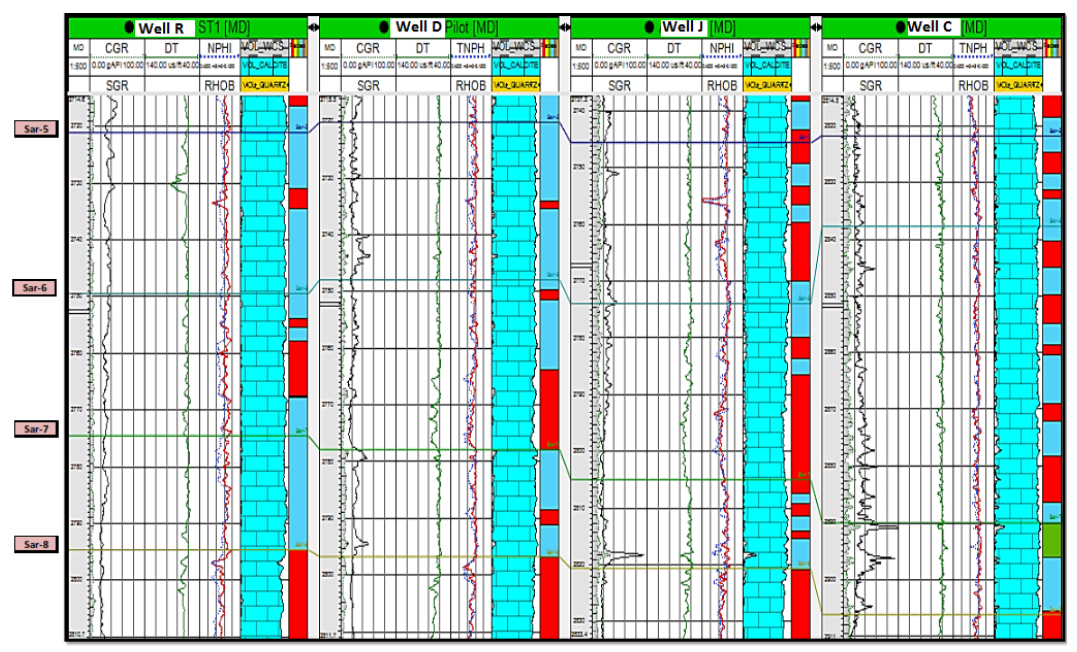

Figure 5. Sarvak lithotypes distribution in zones (Sar-5 to Sar-8). 


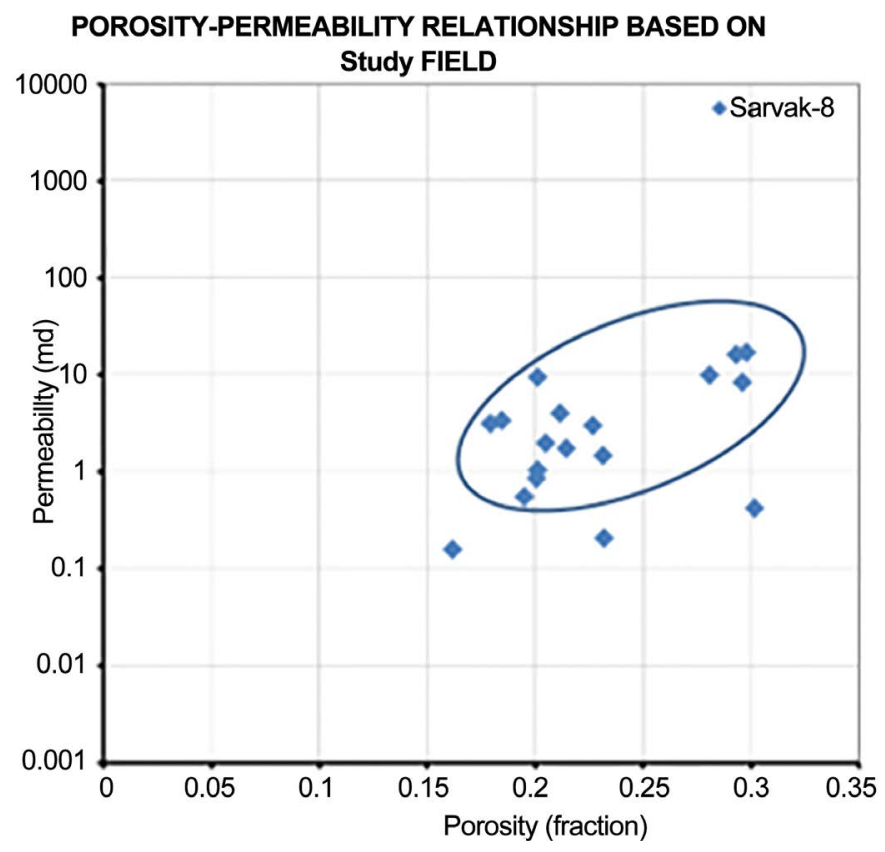

Figure 6. Core porosity and permeability cross plot in the Sarvak Fm. (zone 8), well A.

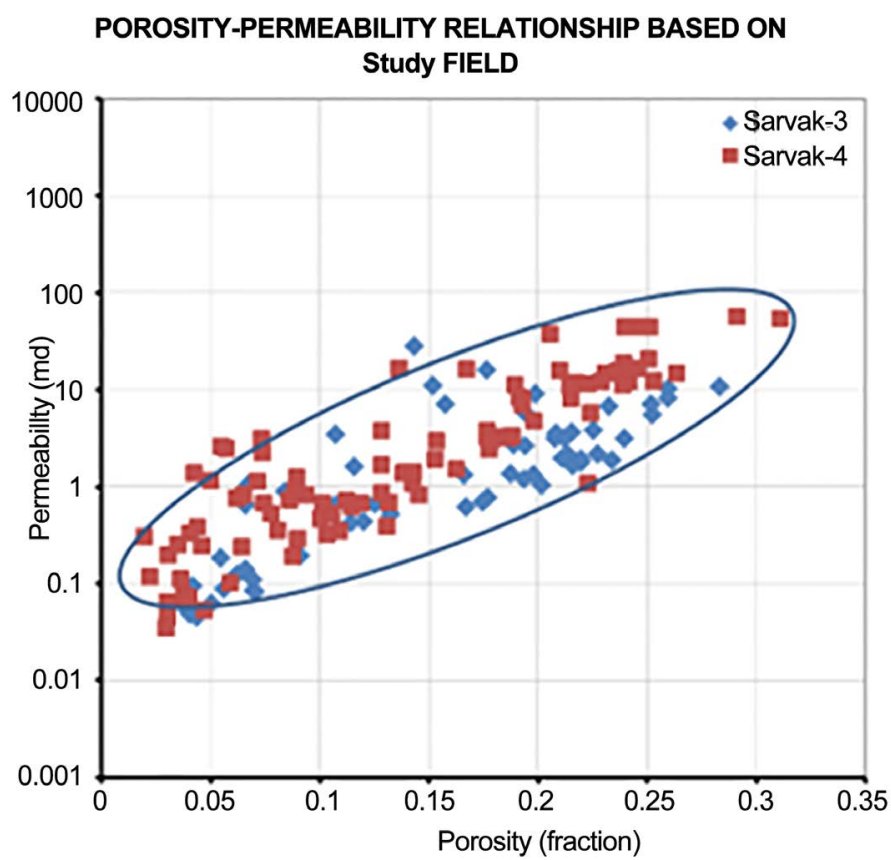

Figure 7. Core porosity and permeability cross plot (zones $3 \& 4$ ), well B.

There are some figures of the selected core images (Figure 10) from Sarvak cored intervals in the study cored wells, representing different litho types, pore types and direct influence of the meteoric diagenesis to improve the reservoir quality. There are some figures illustrating a comparison between the core intervals and the relevant reservoir characteristics that have been carried out on this project in some selected study field cored wells (Figure 11 and Figure 12). 


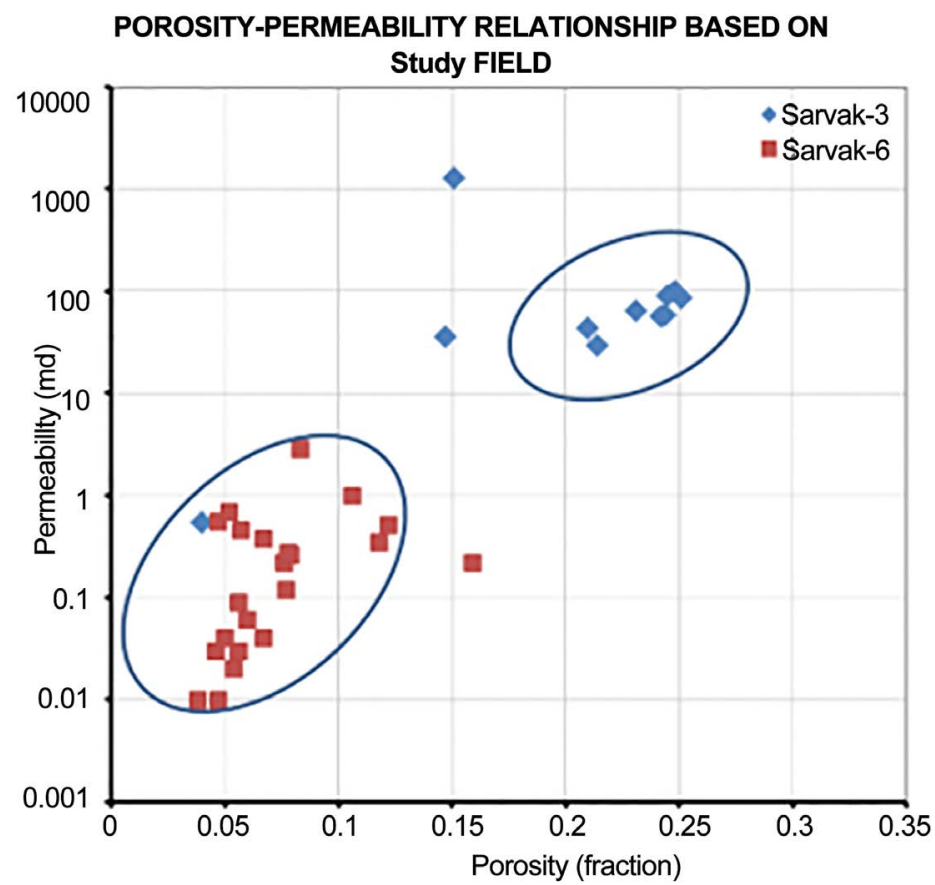

Figure 8. Core porosity and permeability cross plot, zones $3 \& 6$, well C.

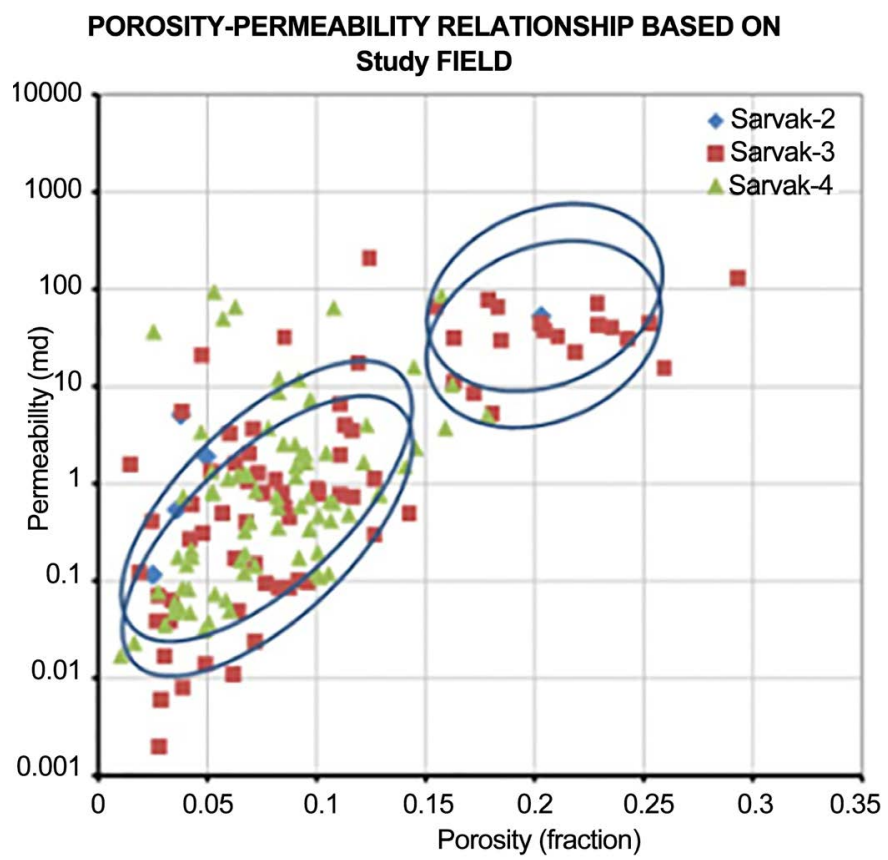

Figure 9. Core porosity and permeability cross plot, zones $2,3 \& 4$, well D.

\subsection{Lithotype Heterogeneity}

The achieved results represents that the Sarvak lithotypes can be followed roughly across the study Field and adjacent areas. There are some lateral heterogeneities particularly in the upper Sarvak interval, which has occurred by sedimentary environment fluctuations. One of the main important sedimentary fea- 


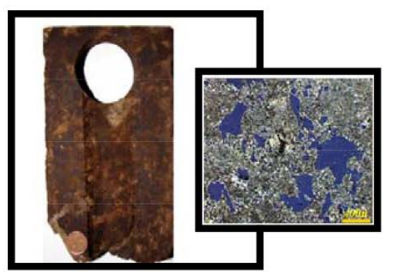

(a)

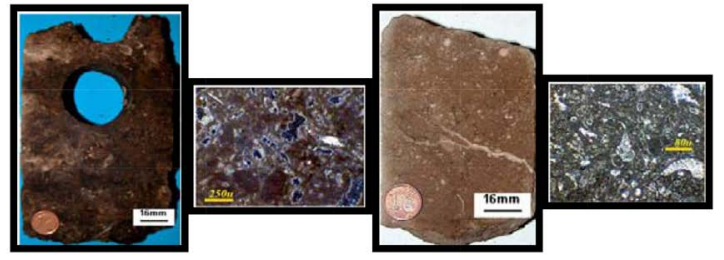

(b) (c)

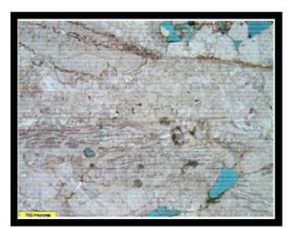

(d)

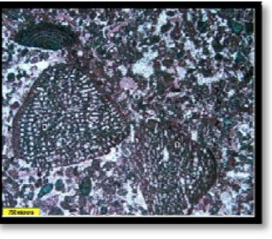

(e)

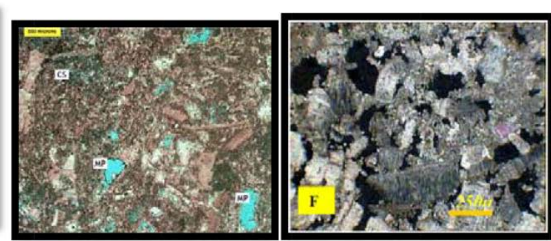

(f)

(g)

Figure 10. (a) Core sample of the Sarvak Fm., Sarvak zone 3, heavily oil-stained with Rudist debris (left) and photomicrographs showing interparticles and vuggy porosity (right); (b) Core sample of the Sarvak Fm., Sarvak zone 3, heavily oil-stained with Rudist debris (left) and photomicrographs showing vuggy and moldic porosity (right); (c) Core sample of the Sarvak Fm., Sarvak zone 3, more argillaceous bioclastic wackestone to packstone with planktonic facies, Sarvak zone 5; (d) Rudist grainstone with intraparticle porosity, Sarvak zone 3; (e) Bioclast/peloid grainstone with benthonic foraminifer such as Orbitolina assemblages, pervasively cemented by secondary calcite; (f) Rudist bearing packstone to grainstone with reservoir quality, Mouldic (MP) after removing of skeletal grains (CS), stained by blue dye; (g) Rudist bioclast grainstone (rudstone) with pervasive interparticle porosity, Sarvak zone 3, outer shelf setting.

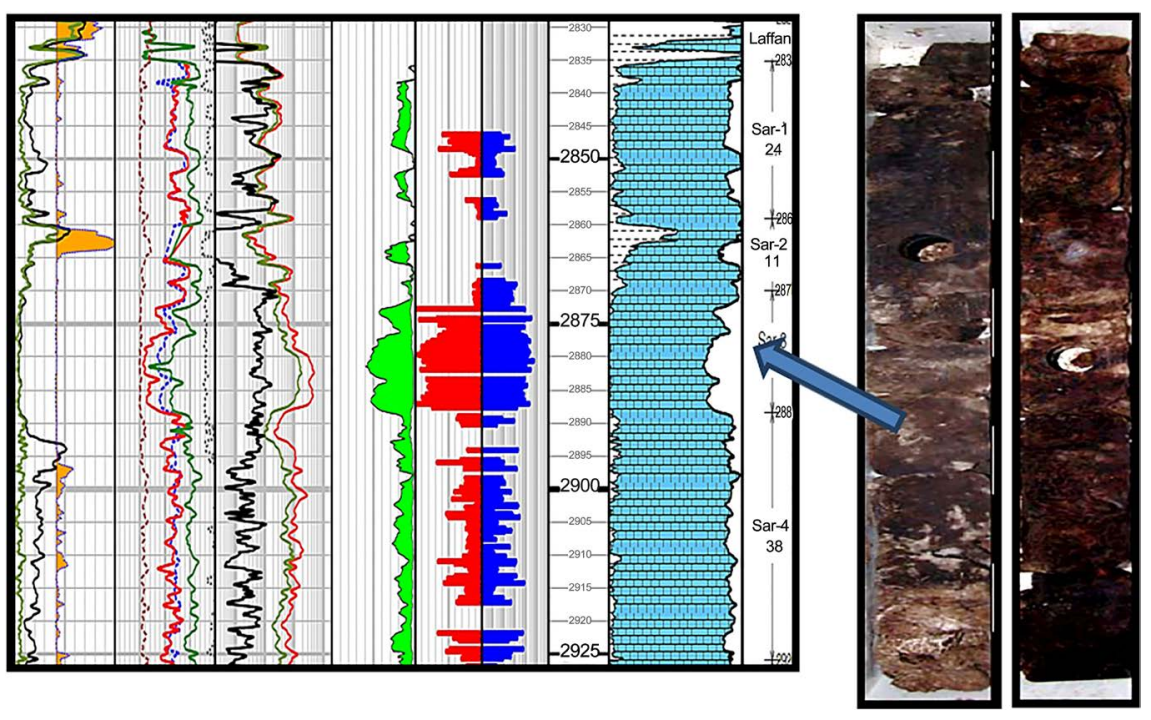

Figure 11. A comparison between cores and log analysis, Upper Sarvak interval, zone 3, heavily oil-stained with large rudist debris.

tures is carbonate bioclastic build-ups, generated by frequent sea level oscillations and settlement of the carbonate platform with builder organisms such as Rudist communities in the study area (Figure 13). The seismic confirmed the presence of particular carbonate build-ups in the Sarvak Formation. The recent study on the Sarvak litho-types reveals the main components of the build-ups is 
large Rudist debris, distributed in different parts of the Sarvak Formation. It is noteworthy that the observed heterogeneity is more focused in the upper Sarvak interval, influenced by eustatic sea level changing and erosion of the bioclastic reef communities in the study area (Figure 14). One of the main parameters used in order to interpret the upper Sarvak carbonate heterogeneity was available Paleologs interpretation. The extracted subsurface data consists of facies associations, fossil index (for instance, rudist life extent along the relevant stratigraphical columns and to have a comparison with its frequency or domination) and depositional settings (from coastal to pelagic facies belts) which have been

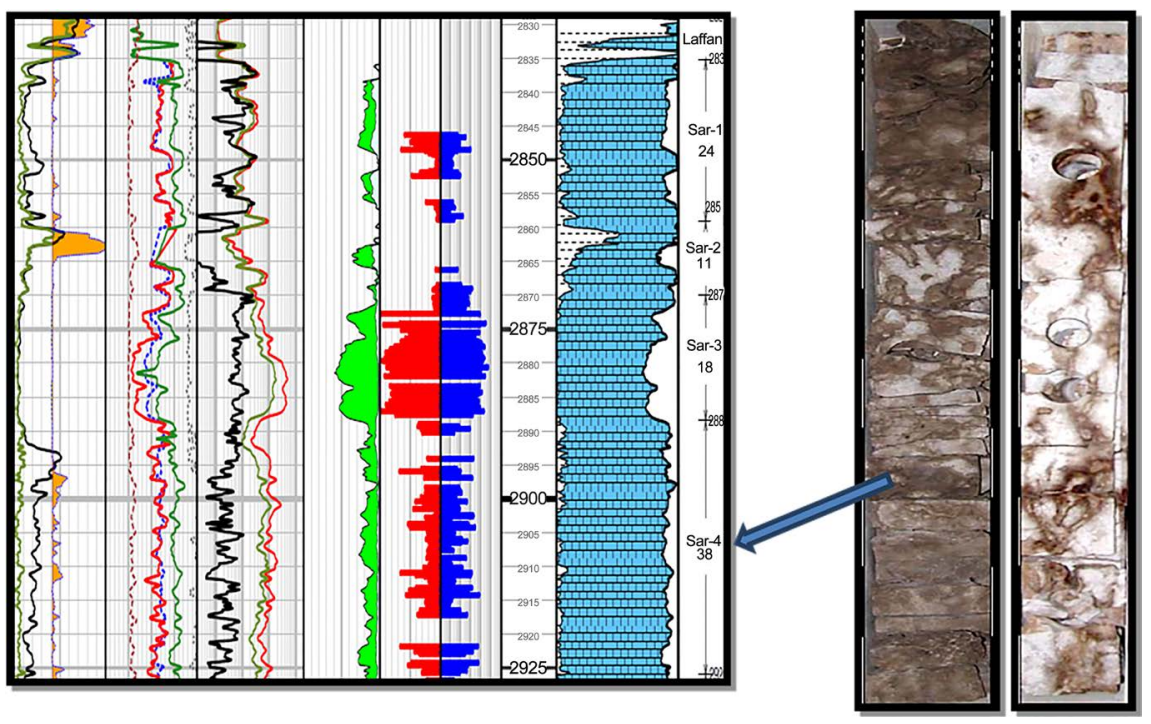

Figure 12. A comparison between cores and log analysis, Upper Sarvak interval, zone 4, karstified interval with partly oil-stained.

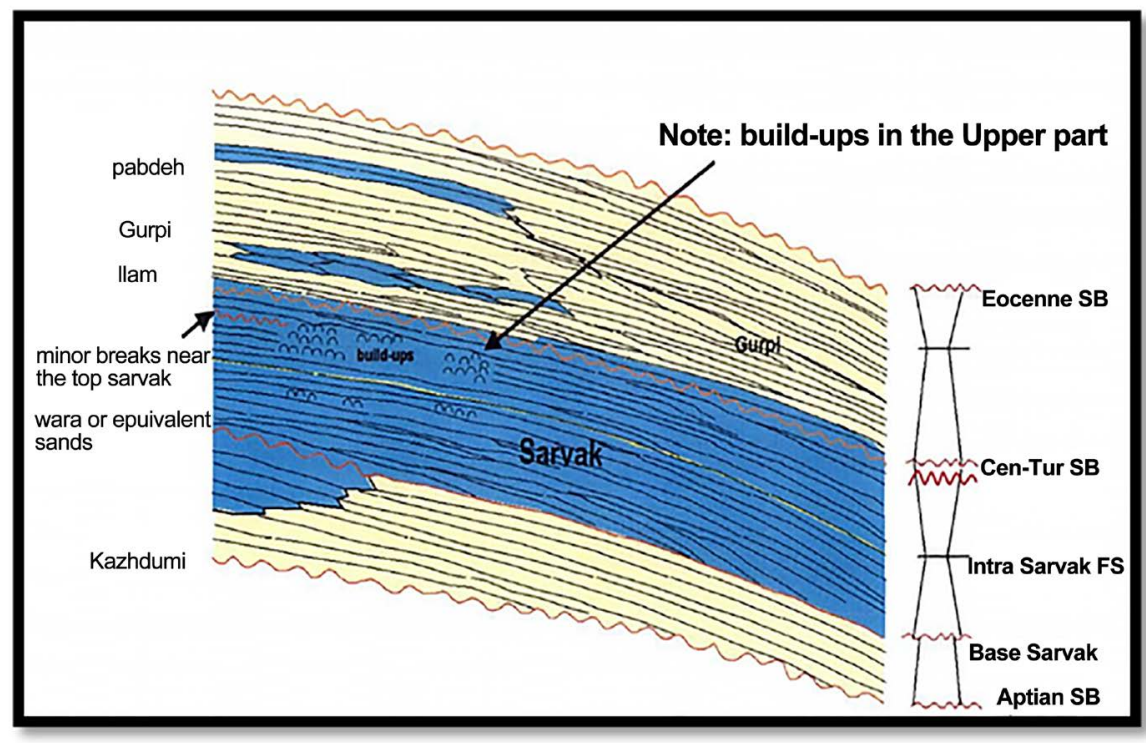

Figure 13. Patchy distribution of bioclastic build-ups in the Sarvak Formation, Abadan Plain region. 


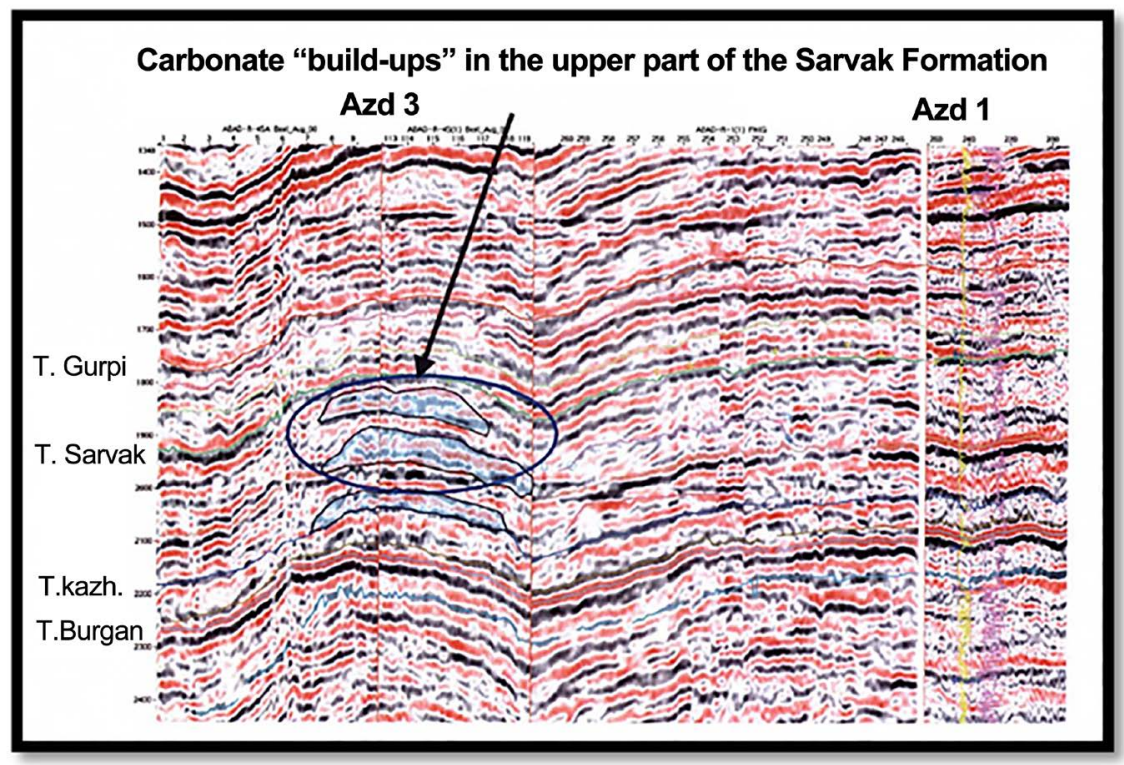

Figure 14. Seismic carbonate build-ups in this field, interpreted by Hydro, 2005.

used for identification of each lithotype extension in the study area. Due to lack of any reliable facies/fossil assemblages data for all new drilled wells in the study Field, some wells which have appropriate petrophysical evaluation, have been chosen in vicinity of the key wells (having Paleolog) to correlate the relevant lithotypes extension throughout the field as a distinct geographical transect. In order to evaluate the extension of the reservoir lithotypes in the study field and adjacent areas, all available Paleologs are interpreted and correlated together from south to the north of study Field, in terms of facies types (lithotypes), index fossil assemblages (vertically and laterally extents).

\subsection{Depositional System}

The following schematic depositional models can be proposed for the Sarvak reservoir formations in the study Field on the basis of the vertical and lateral distributions of the lithofacies types. The introduced depositional models have been proposed according to the review of all geological data from the cored wells and available Paleolog interpretations. Their depositional systems have been interpreted and reviewed, based on these major depositional settings as below:

- Coastal setting: different types of sandstones and reddish claystone.

- Inner ramp/shelf setting: shallow marine carbonate with restricted microfauna and more mud-supported facies and partly dolomitized.

- Mid ramp/shelf setting: bioclastic grain-supported facies with varied types of bioclast and large debris of the reef builders such as Rudist and Corals.

- Outer ramp/shelf setting: bioclastic carbonate with a mixture of mud-supported and grain-supported facies, more diverse open marine microfauna and lesser digenetic impacts.

- Hemipelagic setting: a mixture of benthic and planktonic microfauna, increasing of shale volume, marly facies. 
- Pelagic setting: planktonic microfauna are dominant with noticeable volume of the clay contents, marly to argillaceous facies.

The vertical and lateral depositional systems interpretation for each reservoir formation has been done by use of Paleolog bearing wells in the study Field that are shown in brief in the Figure 15 and Figure 16.

\section{Conclusions}

There are geological/petrophysical lithotypes as Dunham classification that have been revised by received core data. There are distinct affinities between defined lithotypes in terms of facies type, main components and the relevant reservoir

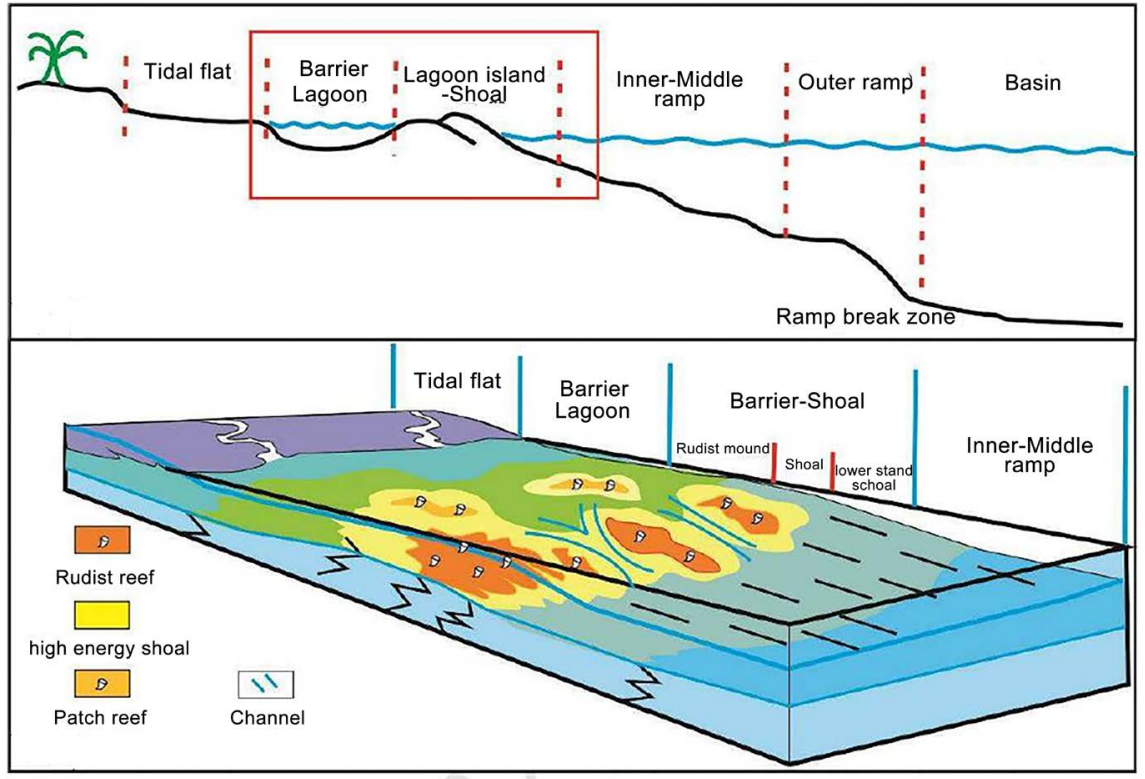

Figure 15. Schematic depositional model of the upper Sarvak interval in the study field.

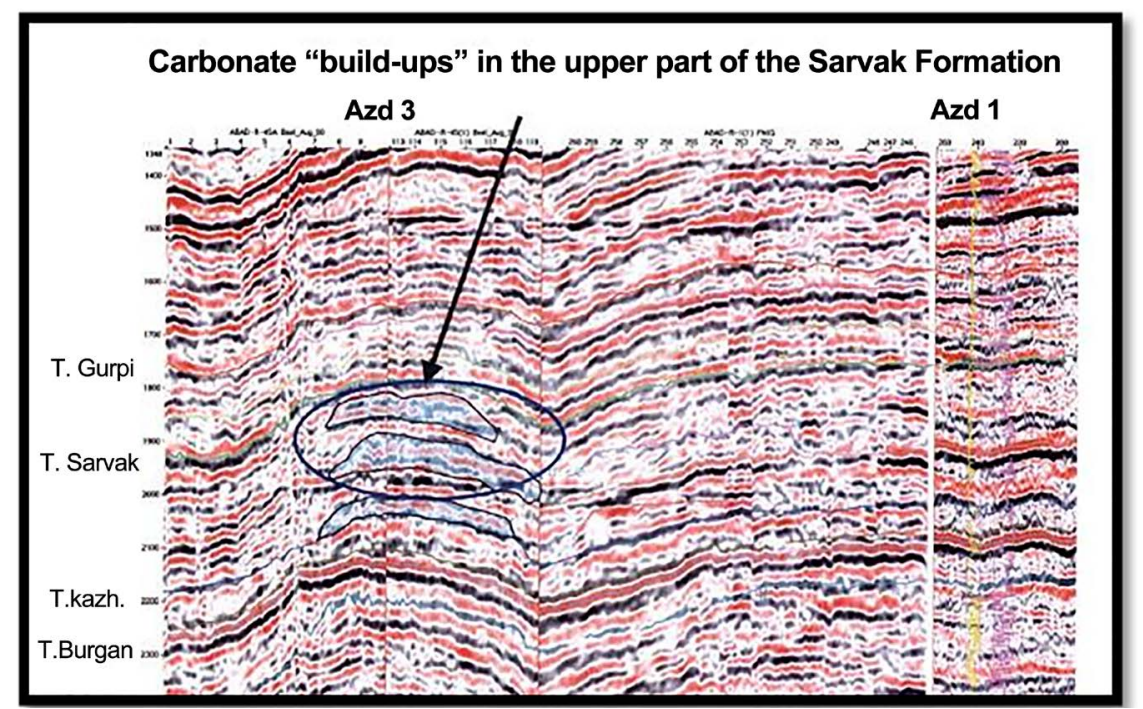

Figure 16. Schematic depositional model of the upper Sarvak interval in the Abadan Plain area. 
characteristics. The distinct microfacies types have also been reviewed in order to interpret the major sedimentary environments for each Sarvak lithotype. As a result, the Sarvak reservoir interval can be characterized by the following correlatable litho types:

- Lithotype 1: Argillaceous muddy to fossiliferous facies (corresponds to the low to non-reservoir rock).

- Lithotype 2: Mud-dominated carbonate facies (bioclastic wackestone to packstone) with partly dolomitized facies (dominantly low reservoir quality).

- Lithotype 3: Rudist bearing facies (medium to coarse grained Rudist/Coral rudstone to floatstone (commonly high reservoir quality).

- Lithotype 4: Mostly cemented bioclastic grain-dominated carbonate facies (peloidal/bioclastic packstone to grainstone (moderate to low reservoir quality).

- Lithotype 5: Claystone (non-reservoir rock).

The Sarvak lithotypes were aggraded vertically and laterally in the study area, caused by eustatic sea level changes and local tectonic activities. The relevant reservoir qualities are significantly controlled by facies properties (grain size, pore type and matrix type), depositional environments and diagenetic impacts (dolomitization and dissolution processes) that increased or decreased the reservoir quality. The reef builder fragments such as Rudist and Coral debris prograded into the outer part of Sarvak basin in the study area, caused by gradual sea level falling and temporary subaerial exposures. Therefore, the medium to large grained bioclastic grain-dominated carbonate facies (mainly is constituted by Rudist fragments) with noticeable reservoir quality and different petrographical porosity types can be considered as the best reservoir facies in the Sarvak Formation. There is a relationship between Rudist packages and still-stand to gradual sea level falling. It seems that the Rudist bearing facies dominated in the upper part of Sarvak Formation, influenced by Late Cenomanian to Early Turonian shallowing upward cycles and several small-scale subaerial emergences (stratigraphical disconformity to paraconformity).

\section{References}

[1] James, G.A. and Wynd, J.G. (1965) Stratigraphic Nomenclature of Iranian Oil Consortium Agreement Area. AAPG Bulletin, 49, 2182-2245.

[2] Wynd, J. (1965) Biofacies of Iranian Oil Consortium Agreement Area. IOOC Report 1082, Unpublished.

[3] Motiei, H. (1993) Stratigraphy of Zagros. Geological Survey of Iran Publication, Tehran, $536 \mathrm{p}$.

[4] Razin, P., Taati, F. and Van Buchem, F.S.P. (2010) Sequence Stratigraphy of Cenomanian-Turonian Carbonate Platform Margins (Sarvak Formation) in the High Zagros, SW Iran: An Outcrop Reference Model for the Arabian Plate. Geological Society, Special Publications, London, 329, 187-218.

https://doi.org/10.1144/SP329.9

[5] Sharp, I., Gillespie, P., Morsalnezhad, D., Taberner, C., Karpuz, R., Verges, J., Horbury, A., Pickard, N., Garland, J. and Hunt, D. (2010) Stratigraphic Architecture 
and Fracture-Controlled Dolomitization of the Cretaceous Khami and Bangestan groups: An Outcrop Case Study, Zagros Mountains, Iran. Geological Society, Special Publications, London, 329, 343-396.

https://doi.org/10.1144/SP329.14

[6] Farzipour-Saein, A., Yassaghi, A., Sherkati, S. and Koyi, H. (2009) Basin Evolution of the Lurestan Region in the Zagros Fold-and-Thrust Belt, Iran. Journal of Petroleum Geology, 32, 5-19. https://doi.org/10.1111/j.1747-5457.2009.00432.x

[7] Ghabeishavi, A., Vaziri-Moghaddam, H., Taheri, A. and Taati, F. (2010) Microfacies and Depositional Environment of the Cenomanian of the Bangestan Anticline, SW Iran. Journal of Asian Earth Sciences, 37, 275-285.

https://doi.org/10.1016/j.jseaes.2009.08.014

[8] Hajikazemi, E., Al-Aasm, I.S. and Coniglio, M. (2010) Subaerial Expsoure and Meteoric Diagenesis of the Cenomanian-Turonian Upper Sarvak Formation, Southwestern Iran. Geological Society, Special Publications, London, 330, 253-272. https://doi.org/10.1144/SP330.12

[9] Hajikazemi, E., Al-Aasm, I.S. and Coniglio, M. (2012) Chemostratigraphy of Cenomanian-Turnian Carbonate of the Sarvak Formation, Southern Iran. Journal of Petroleum Geology, 35, 187-206. https://doi.org/10.1111/j.1747-5457.2012.00525.x

[10] Rahimpour-Bonab, H., Mehrabi, H., Navidtaleb, A. and Izadi-Mazidi, E. (2012) Flow Unit Distribution and Reservoir Modelling in Cretaceous Carbonates of the Sarvak Formation, Abteimour Oilfield, Dezful Embayment, SW Iran. Journal of Petroleum Geology, 35, 1-24. https://doi.org/10.1111/j.1747-5457.2012.00527.x

[11] Asadi Mehmandosti, E., Adabi, M.H. and Woods, A.D. (2013) Microfacies and Geochemistry of the Middle Cretaceous Sarvak Formation in Zagros Basin, Izeh Zone, SW Iran. Sedimentary Geology Journal, 293, 9-20. https://doi.org/10.1016/j.sedgeo.2013.04.005

[12] Asghari, M. and Adabi, M.H. (2014) Diagenesis and Geochemistry of the Sarvak Formation in Ahvaz Oil Field-Iran. Geochemistry Journal, in Press.

[13] Dickson, J.A.D. (1965) Carbonate Identification and Genesis as Revealed by Staining. Journal of Sedimentary Research, 36, 491-505.

[14] Dunham, R.J. (1962) Classification of Carbonate Rocks According to Depositional Texture. In: Ham, W.E., Ed., Classification of Carbonate Rocks, American Association of Petroleum Geologist Memoir, AAPG, Tulsa, 108-121.

[15] Embery, A.F. and Klovan, J.E. (1971) A Late Devonian Reef Tract on Northeastern Banks Island, Northwest Territories. Bulletin of Canadian Petroleum Geology, 19, 730-781.

[16] Wilson, J. (1975) Carbonate Facies in Geological History. Springer, New York, 471 p. https://doi.org/10.1007/978-1-4612-6383-8

[17] Flugel, E. (2010) Microfacies of Carbonate Rocks, Analysis, Interpretation and Application. Springer Berlin Heidelberg, New York.

https://doi.org/10.1007/978-3-642-03796-2 
Submit or recommend next manuscript to SCIRP and we will provide best service for you:

Accepting pre-submission inquiries through Email, Facebook, LinkedIn, Twitter, etc. A wide selection of journals (inclusive of 9 subjects, more than 200 journals)

Providing 24-hour high-quality service

User-friendly online submission system

Fair and swift peer-review system

Efficient typesetting and proofreading procedure

Display of the result of downloads and visits, as well as the number of cited articles Maximum dissemination of your research work

Submit your manuscript at: http://papersubmission.scirp.org/

Or contact ojg@scirp.org 